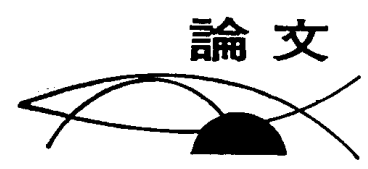

\title{
生体内植迟み人丁: 心臟
}

鷲津卓爾火

\section{1.はじめに}

人工り装置を使用して血液を灌流寸るこ上汇 よって人閒の生命が維持できるといら考え㳉古 くからあり1813年に LeGalloisによって発表志 れている ${ }^{1)}$. その後この問題は次第に現実化し， 1950年代になって開心術を目的とした各種の人 工心肺装置が急速に開発された。体外循環のた めの血液ポンプは生体心臟の拍動に近似するい わゆる拍動流がより生理的で，よい結果がえら れると考えられ，多数の型式の拍動流ポンプが 開発され報告された. 今日，人工心臓として開 発されているほとんどあらゆる型式のものの原 型を寸でにこの時代に認めることができる.

1953 年 Gibbon ${ }^{2)}$ によって初めて体外循環に よる臨床の直視下心蔵手術が成功し，1955年 Kirklin $ら^{3)}$, Lillehei $~^{4)}$, 本邦でも 1957 年曲 直部 $ら^{5)}$ ，榊原ら ${ }^{6)}$ によって臨床例が報告され るにいたって，人工心肺装置も急速な発展をと げた。しかし短時間に終了する開心術のための 体外循環には拍動流でなくてもローラーポンプ なよ゙の無拍動ポンプで充分に目的が達成できる ことがわかり，多数の型式の拍動ポンプは体外 循環には応用されなくなった。近年, ふたたび 無拍動流による体外循環が批判の対象となりつ つあるけれども, 当時多くの研究者は拍動ポン プの次の研究目標を永久绕生体心臟と置換する 植込み人工心臟に変換した. 1958 年 Cleveland Clinic の Kolff や阿久津ら ${ }^{7)}$, Baylor 大学の DeBakey, Liotta ら ${ }^{8)}$ によってこの目的の血液 ポンプがはじめて報告された。

*名古屋大学医学部第 1 外科

(原稿受付：昭和 46 年 3 月 1 日)
1958 年 Harken ${ }^{9)}$ によって報告さ机た Davo! ポンプ沈心電闵に同期して駆動ができ，心不全 の治療に応用寸ることを目的とした。この血液 ホンンフには弁があり血液の一方向への駆動が可 能であるけれども, 補助循環は次第に末梢循環 を犠牲にし，その許容限界まで心機能の改善を 重視する方向に進んだ. SIMAS ポンプ10)で流 弁在なくし，単に血液の往復だけで心機能の補 助长計り，さらに balloon pumping ${ }^{11)}$ では心電 図に同期して大動脈を周期的にしゃ断すること によって冠血流増加を計るもので，人工心臟之 汸明瞭に一線を画すにいたっている。

一方，人工心臟流置の改良によって次第に 灌流時閒が延長するにいたって，血液が高分子 材料に接触することによる凝固が大きな問題と なった．とくに弁に関する血栓形成防止が課題 となり多くの研究が行なわれたが，これらの成 果は 1961 年 Starr ら ${ }^{12)}$ によってボール弁によ る僧帽弁置換術にはじまった各種の人工弁開発 に応用された。 そして逆に現在臨床に奉用され ている人工弁が人工心臟にもとりいれられるに いたっている。

かくして，人工心臓は体外循環のための人工 心肺, 補助循環, 人工弁などと共に古くから研 究されながら臨床応用の面では今なお一歩遅れ た存在である.1969年 4 月 4 日,Cooley ら ${ }^{13)} に$ よって初めて人工心臟への完全置換術が行なお れ，4月 7 日には Donor 心による心臟移植が 行なわれたほかは数例の補助心臟移植が報告さ れたにすぎない。

\section{2. 人工心臓の分類}

人工心臟の応用に当って病的な生体心を切除 

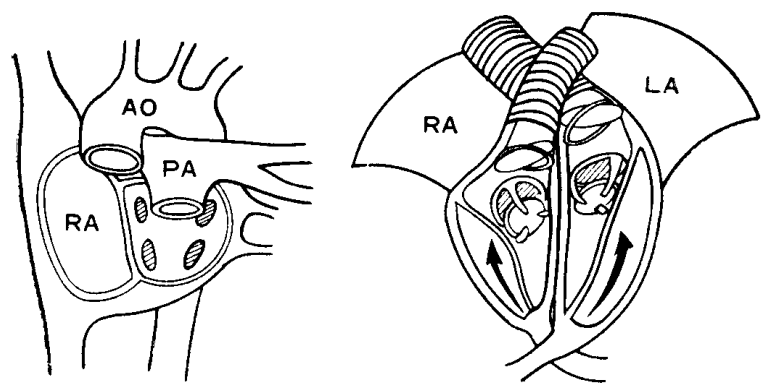

図 1 左の生体心を切除した部分人，右の 人工心臓を移植する total heart

するか, 温存するかによって人工心臟の機能, 形 態は大きくかわる，前者の場合，通常は心房门 一部在残して生体心を切除し，乞の代りに人工 心臟を移植するもので， total heartといわ礼 る.（図 1)人工心臟仙左右の心室上心房備 え，心室の流出路注生体両大血管一縫合できる ように太さや方向もこ机らに適合して製作さ礼 な⿰れればならない，さらに心膜腔内に収納でき る大きさでなければならず，総重量も生体心上 同じかそ机以下にする必要がある。このた内人 工心臟の形態は必然的に生体心類似のもの上な 门，三の変化は少ない。弁注生体心と闰様汇4 つ必要であり，弁の種類とその機能は今後导検 討される課題であ万う。ささらに血液の直接接触 する心房，心室を形成する高分子材料とその駆 動方法などが今後も検討され追求される問題で あるう。

これに反し，生体心を温存寸る場合はきわ的 て多様な人工心臓が考えられている.人工心臟 の移植のための固有の空間がなく，生体固有の 血液循環回路以外に新しく人工心臟のための循 環回路を設ける必要があり, 移植する場所と人 工心臟のための循環回路によって，目的にかな った形態の人工心臟が考案されるからである。 生体心を温存する場合は通常は左心系だけの人 工心臟化が行なわれ，心不全に陥った左心系の 機能回復を期待することを特徵とする.この人 工心臟は，通常は assist heart といわれ心不全 に陥って拍出機能の低下した生体心に代って血 液を末梢へ循環させて左室負荷を軽減し, 同時 に冠血流量の増加を計って生体心の機能改善を 期待するものである. 血液の灌流方式によって 3 つに分類できる. 第 1 は左房から大動脈一人 工心臟によって血液を循環させ, 生体左室の拍

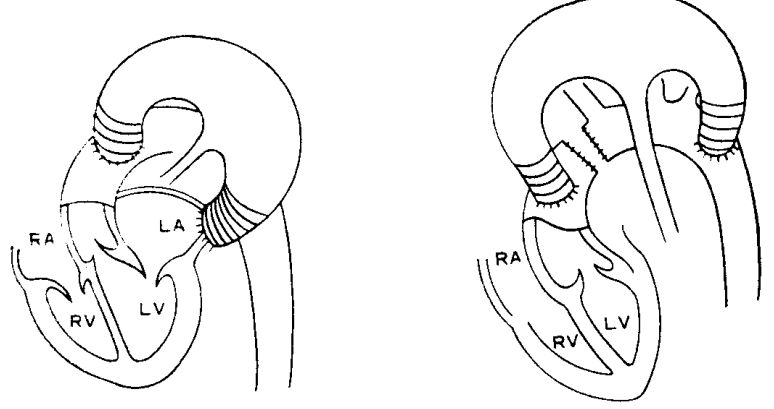

図 2 assist heart の分類, 左は左房一大動脈バ イパス型，右は大動脈一大動脈直列型

出流量を減少させ左室の負荷を軽減するもので ベィ・゙ス型ともいわれる. 第 2 は左室から大動 脈一血液をバイパス寸るもので14)，第 3 の上行 大動をしゃ断しその両端へ人工心臟をいれるシ 》一ズ型15)（図 2）と同じように左室の拍出圧 ェ低下させて負荷の軽減を計るものである。こ 和らのいずれもが生体心の拍動を前提としてお 门，負荷の軽減を目的とするから人工心臓の駆 動によって生体心の拍出が妨げられないよう生 体心之同期駆動することを原則とする.

assist heart の目的をもっとも容易に果すこ 上ボできのはシリーズ型で，生体心の駆出を 大動脈弁を経ていったん全部人工心臟に吸引 し，生体心の应張期にこれを末梢と冠動脈一駆 出する方法である. 人工心臟への吸引に除圧を 使用す机ば左室拍出圧をゼ口にすることが可能 で，左室の心房化といわれるように ${ }^{15)}$ 左室負荷 の軽減効果は大きい，抎張期駆出型であるから 冠血流の増加効果も期待できる.さらに人工心 臟としては弁が流出路に 1 つだけでよいのも利 点である. しかし assist heart の目的が生体心 機能の回復を期待することにあり，この人工心 臟を植込んだ場合には不要になった時点で切断 した大動脈を再縫合し，人工心臟をとりさるこ とがほとんど不可能である. また，生体心機能 回復の段階で漸次左室負荷を増加させる駆動が 必要となるが，この人工心臟にはこういった駆 動方法がない。

左室から大動脈へバイパス駆動するものは左 室へ充分に太いカニューラを挿入すれば前者と ほぼ同じ効果がえられ，この場合はバイパス量 在調整することによって左室負荷の漸増が可能 である。しかしバイパス効果をあげるためには 
大動脈径に近い直径のカニューラが必要であ り，保護の対象となる左室壁に手術侵襲を加え なけれ隹ならないが欠点であるう。

左心房から大動脈へバイパスする方式の人工 心蔵俩手術侵襲が比較的少なく, 胸腔外一移植 す扟济切除に開胸術を必要としない長所がある が，左室負荷の軽減効果がえられにくいのが欠 点である.この人工心臓の大動脈への駆出の時 期は生体心の拍出在妨げないように，また冠血 流量を增加させるためにも拉張期を選ぶ必要が 亦る。关うすると必然的に左房からの吸引注拉 張末期から収縮期に行なわなければならない。 この時期の左房の充満は必ずしも充分でなく， また吸引時間を長くとることができない，左房 加ら短時間内に吸引するため強い陰圧で吸引す るニ上㳉, 肺静脈系の虚脱索ひき起こす危険沙 あり避汁るべきである。左室一流入する血液量 を允分に減少させ，バイパス効果をあげるため に注拡張期の全期に扎たって弱い㓌压で吸引す ること名必要で交り，そうしないと補助効果孛 るるここぶきない。

\section{3. われわれの人工心臓}

われわれは1968年，人工心臟の開発に着手す るに当って ${ }^{(6)}$, 当時きわめて困難である上考え 万机ていた心筋硬塞症の早期血行再建術の術 爱に灾用すること定目的とした。従って total heartで泫なく，生体心を温存し，左室負荷の 軽減を計る assist heart を考えた. 血行再建術

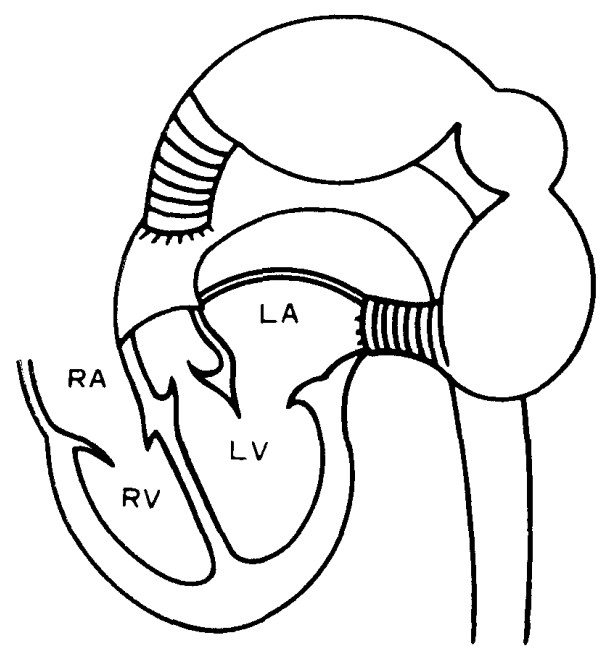

図3われわれの人エ心贜
を行なうことを前提としたため，当然一定期間 後の心機能可復を期待し，人工心臟の効果と共 に心機能回復時の切除の容易さを重要視した.

前にのべた手術侵襲の比較的少ない左房一大 動脈バイパスの灌流方式を採用し，シリ一ズ方 式にみられる効果をうることを計った。われわ れの人工心臟は大動脈一血液を駆動するための chamber と左房から吸引するための chamber 在別途に設けた。生体心の搪張期に同期して一 方の chamber で印っくと全期にわたって左 房から血液を吸引すると同時に，もう一方の chamber で大動脈一血液を駆出するものであ る. (図 3)

生体内植込み人工心臟で今な拉問題とされる のは血栓形成であり，とくに弁に関してはその 機能と共に弁による血栓形成が問題とされてき た。さきにのべたようにこの研究は人工弁の発 達を刺韩し, 現在の弁膜疾患付対する人工弁置 換術の隆盛みたわけであるけれども，現在臨 林に使用されるすべての人工弁が血栓形成に関 しては完全に解決されたものではないことは周 知の事実である。人心臟に扔いては，この弁 と，いまだ解決されたとはいえない高分子材料 空使用した pumping chamber について血栓形 成の程度を比較した場合に弁に比べて chamberにできにくいことが認められている17.

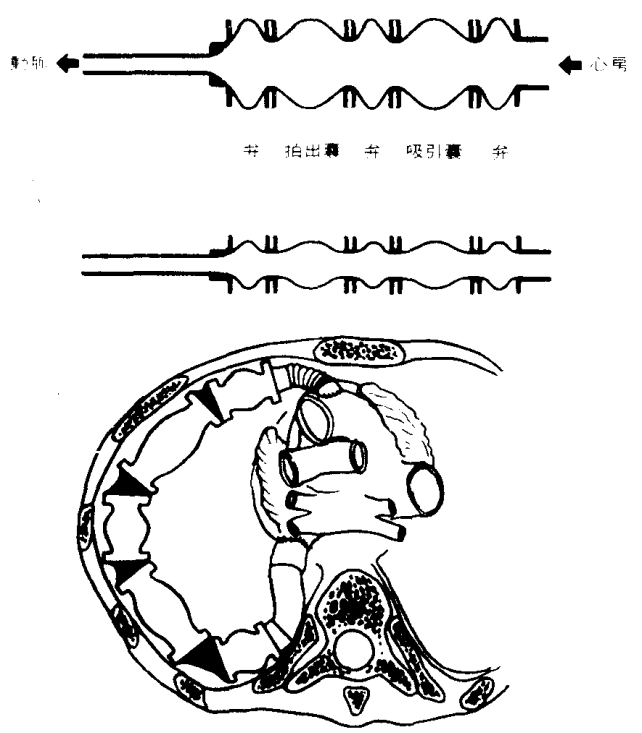

図 4 上の 2 つは人工心臟の chamber, 下は胸腔内へ植込んだ図 
( 28 )

われわれの人工心臟には $2 つ の$ chamber の 中間と両端に合計 3 つ弁を必要とするが，こ れらの事実から内部に植込む弁を避け，すべて 外部駆動弁を採用した. 従ってこの人工心臟は 2 つの駆動用 chamber と3つの小さい弁用 chamber を連社た 1 本の管状構造となった。（図 4)

外部の硬いプラスチック枠の間で彎曲させ, 全体に大きく半円状に曲げて胸壁にそって固定 することを予定した。

図 5 は，この人工心臟の駆動を模式化したも ので，生体心電図の $\mathrm{R}$ 波に同期して，両端の弁 用 chamberを抢しつぶし閉の状態とし，中間 の弁を開いて吸引用 chamber の血液老駆出用 chamber に移動させる。この動作は血液回路に ほとんど抵抗がないから短時間に終了でき，中 間の弁を続いて閉鎖する。生体心の抎張前期に 同期して両端の弁を開き，駆出用 chamber か ら大動脈一血液を駆出すると同時に抾張期の全 期にわたって吸引用 chamber 几左房から血液 を吸引するものである。

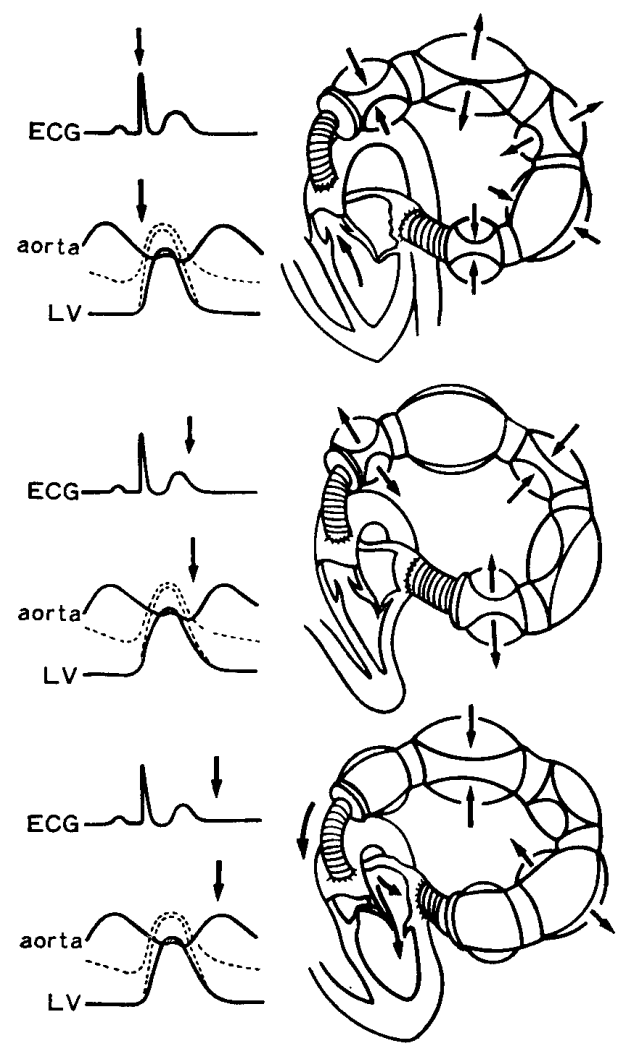

図 5 人工心臓の駆動

\section{4. 人工心臓 chamber の材料と デザイン}

人工心臓の血液が直接ふれる部分は，chamber から先端のカニューラなどの生体への接続 部分まで含めて，使用された高分子材料とそ二 を流れる血液の動態が血栓形成を防止するため にはきわめて重要な因子である。内部に血流の 停滞，貯溜や逆流などが多いと血栓は容易に形 成さ机る。

これらの血流動態を決定するのはこの部分の 形態的なデザインである。この部分に使用され た材料自身の性質と血液駆動のための高分子材 料の運動方式が人工心臟の機能的な寿命を決定 する因子となる．材料の運動方式を決めるのも また chamber のデザインであるから，人工心 臓の宿命ともいえる血栓形成と材料疲労の問題 は材料の選択とそのデザインによって決定さ杞 るといっても過言ではない。

人工心臓の chamber 形成する高分子材料 としては古くからシリコンゴム，ウレタンゴ ム，天然ゴムなどの長時間の駆動を行なっても 血液中に重金属イオンなどの毒物がでない材料 が使用されてきた。しかし，これらのいずれ子 が久点をもち，新しい材料の開発がのぞまれて いる.

現在, 主として米国でこの目的のために開発 されつつあるものに従来のシリコンゴムにアン モニウム塩 (TDMAC) や, ケイ素化合物 silane の誘導体 (APTES) ${ }^{19)}$ を媒体としてその表面に ヘパリンを結合させ血栓の形成を阻止するもの がある. 新しいポリマーとしては正負のイオン をもったものを結合させた poly electrolyte complex (ioplexes) ${ }^{20)}$ や親水性がある polyacrylamide (hydrogel) ${ }^{21)}$ などが開発され検討されて いる.

また一方，これらの高分子材料で製作した膜 の表面をケバ立たせたり (flock) ${ }^{22)}$ ，ビロード状 (velour) ${ }^{23)}$ にし積極的にフィブリンを定着さ せ，偽内膜定つくらせ，さらに注織培養した 細胞を植えて内膜を形成させる方法が試みられ ている.

これらの新しい材料は，いずれも血液に対し 
ての抗凝固性を中心に開発されたものである が，機械的強度についても検討されなければな らない．血栓形成防止にいかにすぐれていて も，運動疲労の著しいものは使用できない．偽 内膜を形成させる方法は血栓形成防止の見地か らはすぐれているが，単純なダイアフラム運動 など chamber の動きが制限されないと強度が えられない欠点がある．例えばこの材料を使用 してわれわれの人工心臟の弁の chamber を製 作しても内膜の厚さによっては破損が生じる心 配がある。

われわれの人工心臓は現在わが国で入手でき る通常の医療用シリコンゴムを使用した. 弁の 部分に関しては開の場合に血流抵抗ができるだ け小さく, 閉の場合に逆流を生じないことが重 要である. 駆出, 吸引用の chamber はふくら んだ時とつぶれた時の内容積の差が大きいこと が望ましい.シリコンゴムの運動に関してはこ の材料は薄く作れば折れ曲げ運動には比較的に 強いが，伸び運動や引っぱりに弱い性質があ る.

図 6 は, これらのシリコンゴムの特性を考慮 して，血液の駆動に際して chamber の運動が 少なく，一部分に伸びや縮み運動が集中しない ように解析幾何的に分析した曲面である．基本

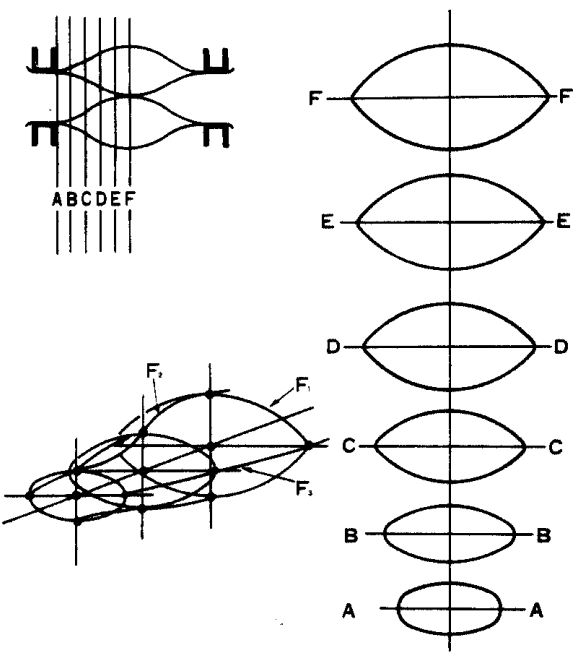

図 6 chamber の断面, $F_{1}, F_{2}, F_{3}$ は函数

的には 3 つの函数から成り立っている ${ }^{24)}$.

シリコンゴムはまたケイ素化合物のポリマー であるがきわめて多数の重合法がある．形成さ れたシリコンゴム膜は材料は同じでも重合法に

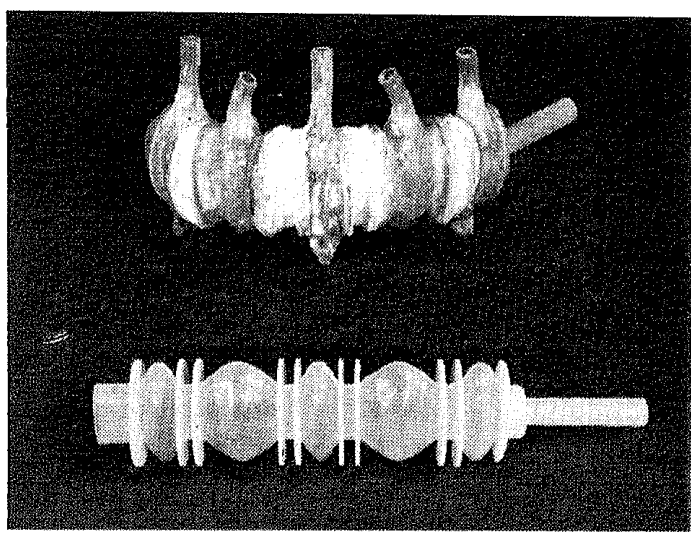

写真 1 上は人工心䑏，下はシリコンゴム 製の chamber

よって本来の性質がえられない場合もある．各 種の重合法を検討した結果，金属型による加圧 加熱法がすぐれているのを知ったので，上記の 函数曲面構造をもった金属型を製作した. 大動 脈カニューラまで一貫して製作するので内面は 完全に平滑で，継ぎ目はない（写真 1.下）

このシリコンゴムの chamber は,それぞれ固 いプラスチックカバーをつけ全体に大きくU字 型に彎曲させ，胸腔内へ容易に収納できるよう にした.（写真 1. 上）

\section{5. 駆 動 機 棧}

NIH の人工心臟プログラムには implantable energy system という研究課題 ${ }^{25)}$ があり，エネ ルギー発生源から変換器まですべてを生体内人 植込むことが計画されている．しかしまだ寒用 段階でなく，エネルギー発生装置，変換機構な ぞに多くの問題がある. 一方, 人工心葴開発の 初期には小型モーターや電磁ソレノイドなどを 直接胸腔内一植込み電気エネルギーを胸壁外か ら供給する方式が試みられたが26)27)，熱の発生 があり，回転力やそのほかの直接えられた機械 エネルギーは人工心臟の駆動には適さなかっ た.

従って, 今日人工心臟の大部分の駆動法は胸 壁を通してガスまたは液体などの流体を作動さ せ，エネルギーを伝達し，血液を駆動する方式 である. 図 7 は assist heart の場合の生体心と の同期駆動法を示したものであるが, total heart の場合も大差はない，生体心に同期させるため の信号源としては心電図のほかに血圧波型が応 


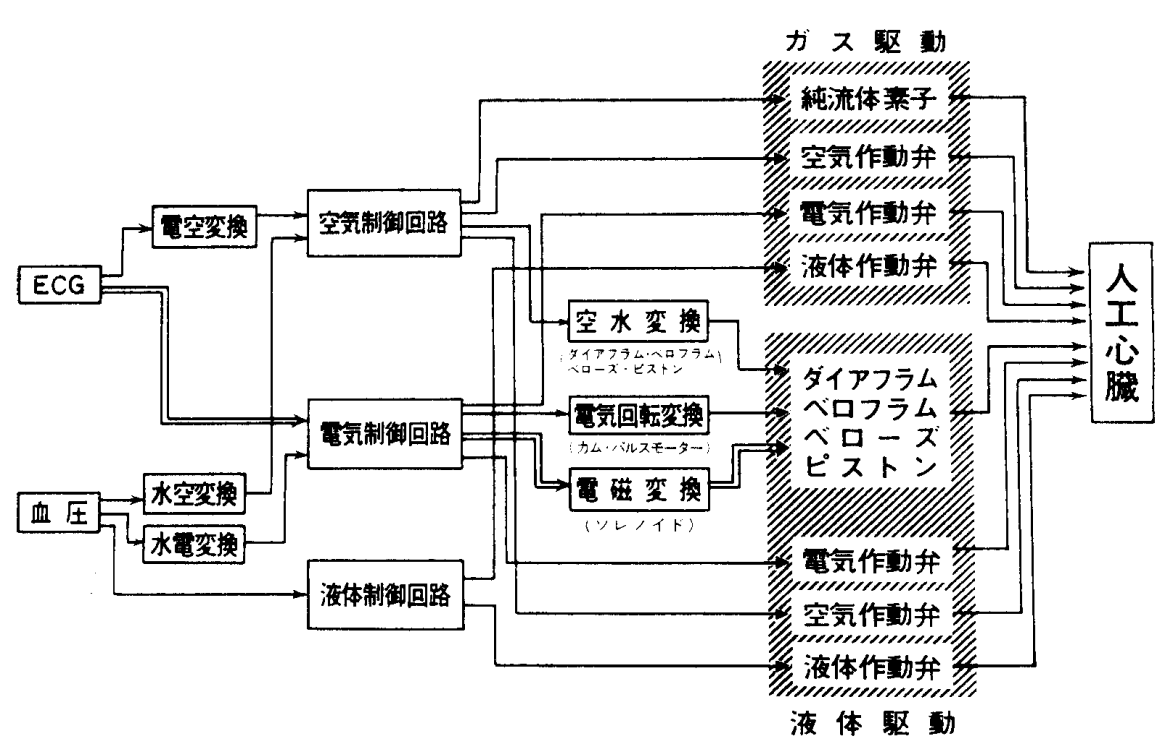

図 7 人工心臓 $の$ 同期 駆動方法
することができるのが将来 人工心臓の臨床導入には大 きな長所となるものと思 う。しかし, エネルギー伝 達の忠実度が高いのが逆に 欠点ともなり駆動機構が粗 雑であると作動初期の衝撃 波や異常高圧波なども忠春 に血液に伝える。またガス に比らべて粘性が高いため 導管を太くしなければなら ない。

わ扎れの人工心臓の駆 動機構は，図 8 に示したよ うに心電図に同期制御され
用でき, 流体制御回路を使用する場合は好都合 である。

現在もっとも多く利用されているものは心電 図を信号源とし電気制御回路によって電気作動 弁を制御したガス駆動方式である. ガス駆動方 式は胸壁を貫通するガス管が比較的細いもので 上く，単純な制御回路で好成績がえられ，手軽 であるのが多く利用される理由である。

しかし，われわれの人工心臟の場合には生体 心の 1 拍動について 5 つの chamber を正確な 時間差をつけて開閉させなければならず，正確 さと速い応答が必要である. 純流体 素子を応用した回路をはじめ28), 空 気作動弁 ${ }^{29)}$, 電気作動弁などによる ガス駆動方式を検討したが，いずれ も満足な結果がえられなかった。ガ ス駆動方式では駆動用弁の部分で例 えば陰压から陽圧に切り換えるとガ ス導管から人工心臓までのすべての ガス回路が陽压になってはじぬて camber が動き血液が駆出される. この間の時間おくれが大きく, エネ ルギー伝達に歪が大きいのが久点で ある.これに反し，液体駆動の場合は駆動液体 自身に伸縮がないためエネルギ一伝達に遅れや 歪がないのが長所である. またガス駆動の場合 はどの方式をとるにしてもかなり大きな音の発 生を伴うのに反し, 液体駆動では容易に無音に
た電気エネルギーを值接電磁ソレ/イドとダイ アフラムによって液体エネルギーに変換し人工 心臟を駆動するものである.

電磁ソレノイドは, 可動鉄片が電磁コイルか ら離れるに従ってトルクが急激に減少する性質 がある。駆動初期の液体エネルギーに不足をき たすので，逆に電気エネルギーは初期に多くな るよう高圧電源をコンデンサーに蓄積しこの 放出パルスと定常電源を重䄈る特殊な出力回路 をSCR を応用し開発した。（図 9)

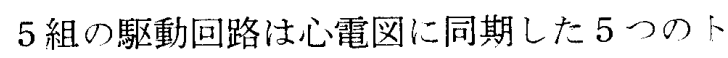

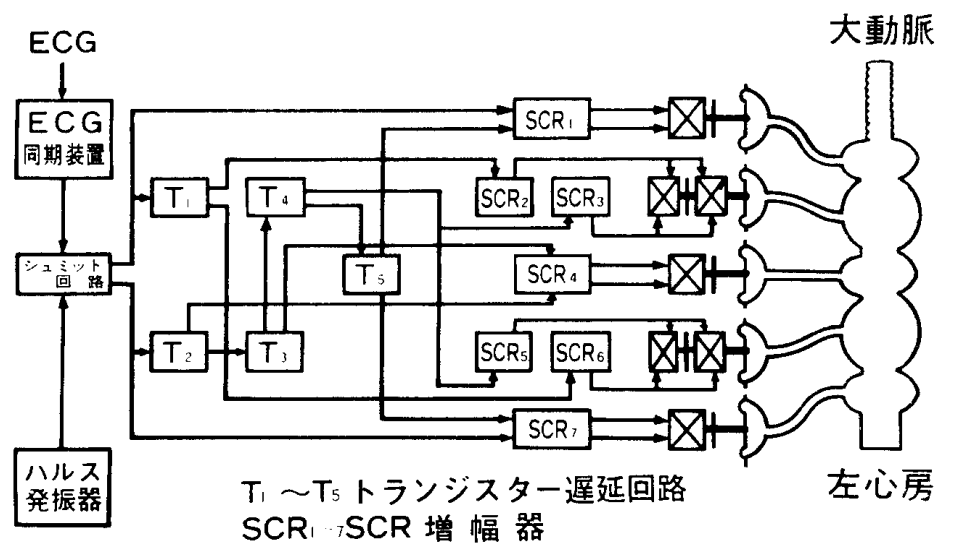

図 8 われわれの人工心臟の駆動機構

ランジスタータイマーによってそれぞれ時間差 をつけ，人工心臟を駆動するが，この方法はい わゆるシーケンス制御であり，制御方式として はのごましない，図10に示したのは，液体回 路加半導体圧力検出素子在利用して弁の開閣 


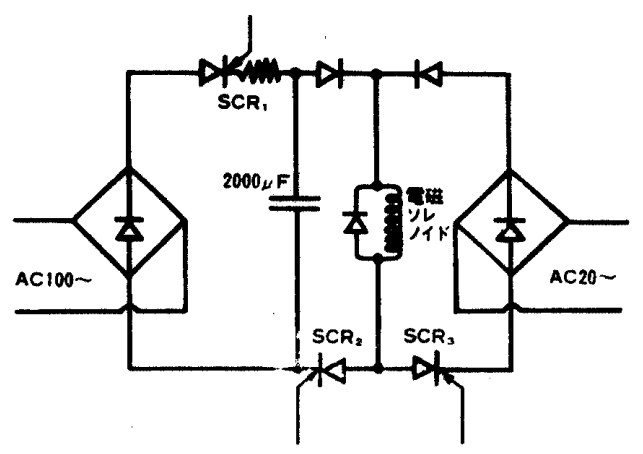

SCR山カ回路
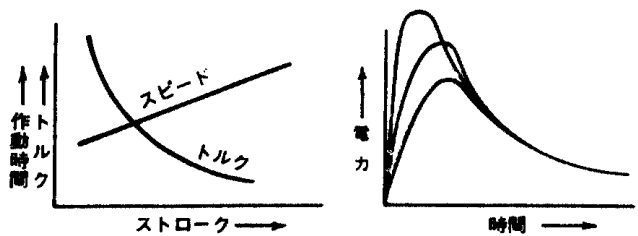

図 9 左下はソレノイドのスピードとトルク, 右 下はパルス状の源, 上は SCR 出力回路

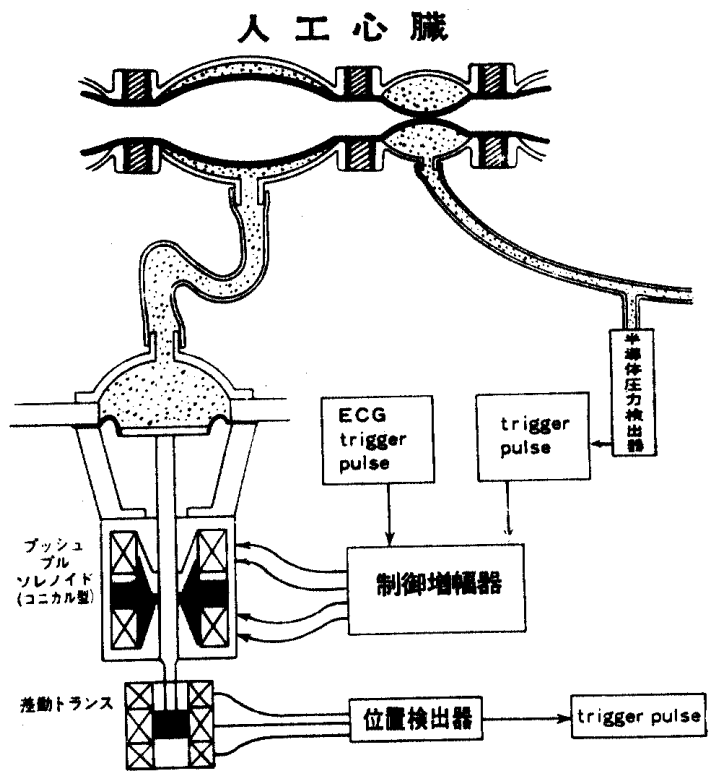

図 10 人工心膕のフィードバック制御

信号をとり，フィードバック制御を計るもの で, chamberに関しては差動トランスを応用し て液体量を検出するものである。これらの回路 は現在試作中であり，近くフィードバック制御 に変更する予定である.

写真 2 に示したのは, この実際の装置で，上 部にダイアフラムがあり，下部に SCR アンプ やタイマー群がある.

なお，この装置に使用している電磁ソレノイ ドは比較的長いストロークのとれるコニカル型

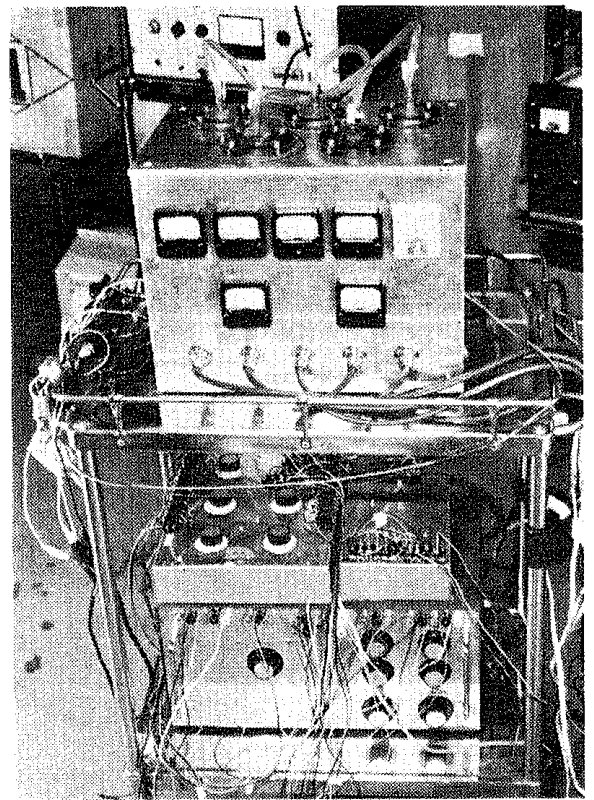

写真 2 上はダイアフラム群, 下部が 制御機器

のもので, 駆出吸引用の chamber に関しては このプッシュプル型のものの両端にベロフラム を装着したものが1つあればよいことがわかっ たので，この部分の小型軽量化を検討中であ る. 差動トランスを含めてこの部分を軽く小さ

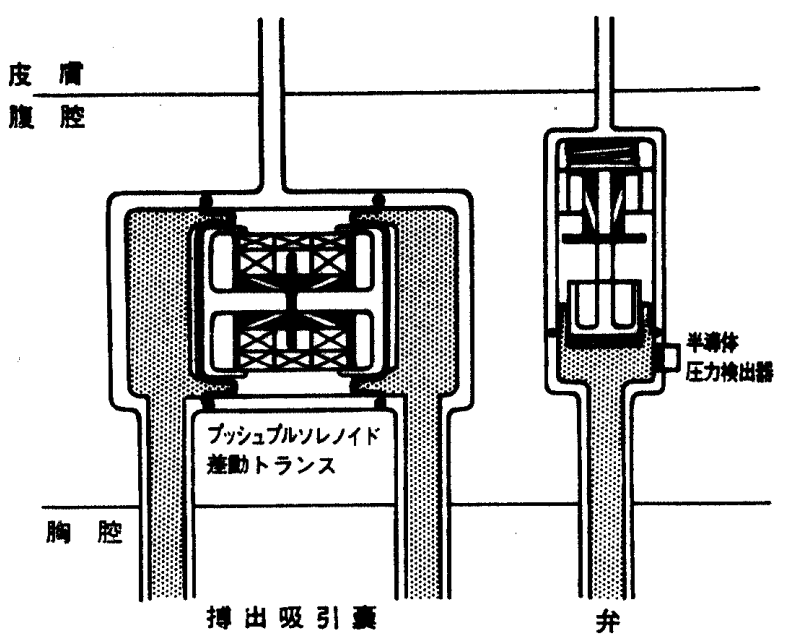

図 11 変換器の小型轻量化による腹䐋内移植

く製作することができれば，できるだけ人工心 臓に接近させて使用し液体導管を短縮すること ができる．理想的には，図11に示したようにこ のエネルギー変換部分は人工心臟と同時に生体 腹腔内一植込み, 電気エネルギー供給回路と信 号回路だけで生体と装置を接続することが望ま れる。 


\section{6. 実 験 成 繶}

人工心臓自身とその駆動機構の改良の都度, 模擬血管回路を使用して駆動条件や血液駆出波 型などを記録し検討した. 図12に示したのは， この 1 例で人工心臓だけの駆動圧波型である. 末梢動脈圧は模擬血管系の大動脈に当る部分に Latex 管を使用したため個有の振動がみられる が, トランジスタータイマーの時間設定が適切 である場合には左房への逆流もみられず，ほぼ 満足すべき結果がえられた. 生体心拍毎分 100 回までは 1 回拍出量の減少をみることなしに同 期駆動できることを知った.

この人工心臓の生体への装置は, 図13に示し たように大動脈側は上行大動脈へ内径 $10 \mathrm{~mm} の$ テフロン代用血管を縫合し，その内部へ人工心 臓の動脈カニューラの先端が大動脈内一到達す るまで挿入し，代用血管の外部から結禁するこ とによって固定した. この方法は大動脈をしゃ 断せずに人工心臟が移植でき，またその除去に

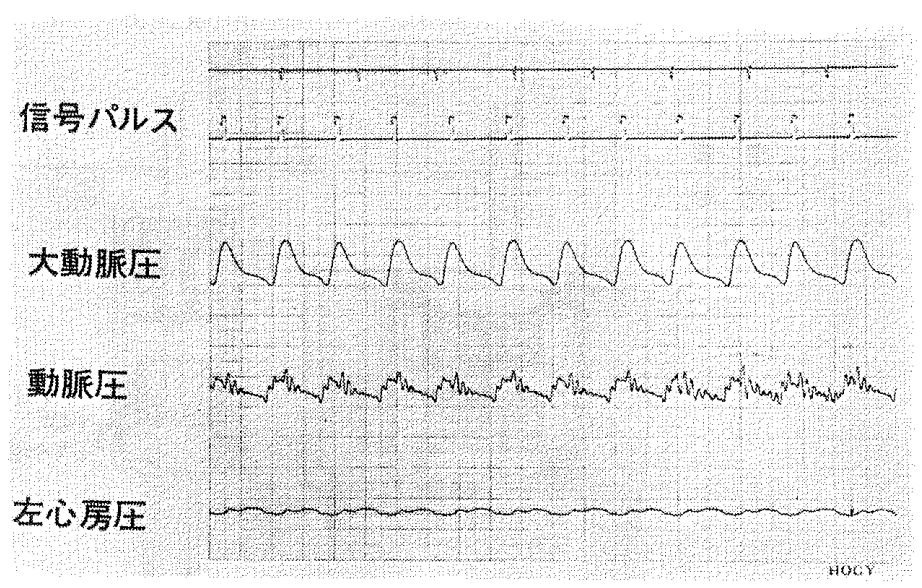

図 12 模擬血管系を使用した人工心㑘の駆動圧波型 た.

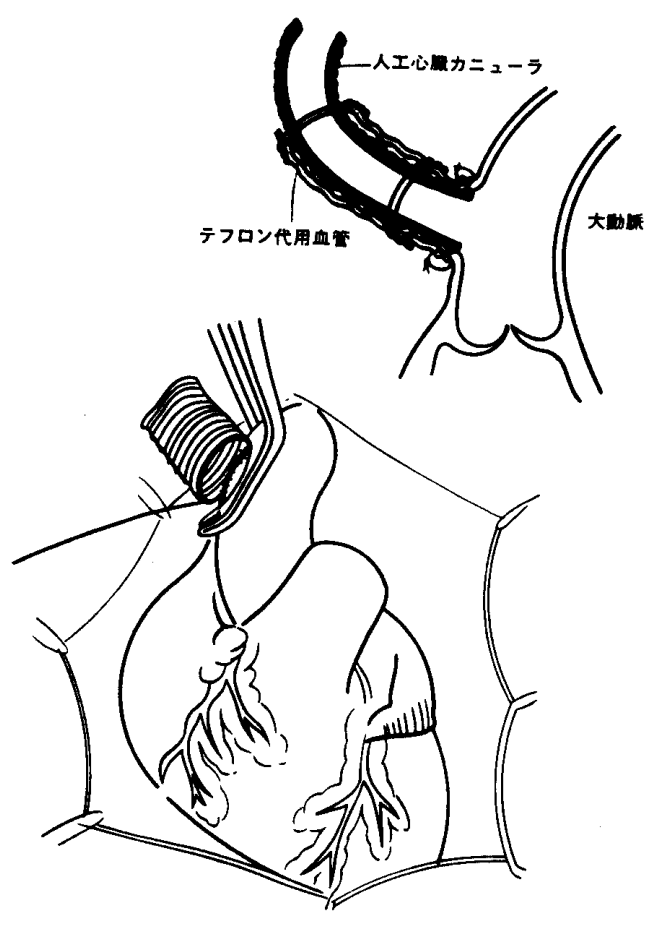

図13大動脈への装菁法

コネクターを使用し, 空気除去のパイプを設け

体重 $10 \mathrm{~kg}$ 前後の雑種成犬を使用して実験を 行なった. イソゾール腹腔内投与で麻酔 し, 挿管後はバード呼吸器で呼吸管理を 行ない，第 5 肋骨床で胸骨横断による両 側開胸し，上行大動脈一血流をしゃ断せ ずに代用血管を縫着し，同様に左心耳に テフロン代用血管を縫着し，止血をまっ て人工心蔵を装着した. 写真は装着を終 了したところである. (写真 4).

左肺静脈から左房へ, 左室尖端から直 接, および大腿動脈から大動脈へカテー テルを挿入し血圧を測定し，同時に上行 大動脈大腿動脈へ電磁流量計のプローベ を装着し，血圧と循環血流量を検討し 際しても結禁を除き，カニューラを抜去して代 用血管の外部から縫合器によって簡単に修復で きるからである．また，血液の直接触れる部分 に人工心臟に使用されたものと異質の高分子材 料が存在しないことも血栓形成防止の見地から 望ましい。

左心房側は写真に示したカニューラを心耳に 大動脈々同様の方法で代用血管を縫着し插入固 定した. 左心房カニューラと人工心臟の間には
た. 図14は，この1例を示したもので，人工心 臟の脈駆動によって左房圧, 左室圧の低下, 大 動圧の拡張期における上昇がみられる.

7.おわりに

人工心臟は total heart にしても assist heart にしても現在までに数多くの型式のものが考案 され，動物実験によって検討されてきたが，今 なお近い将来に日常の臨床に導入される形勢は 


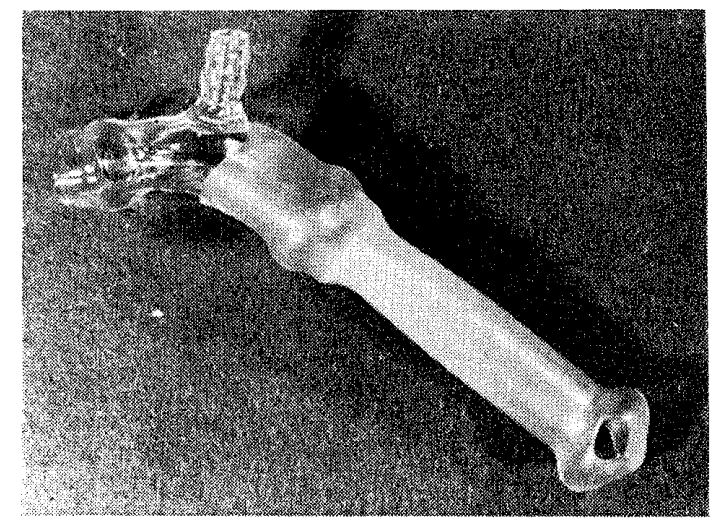

写真 3 心厗カニューラ, 左はコネクター

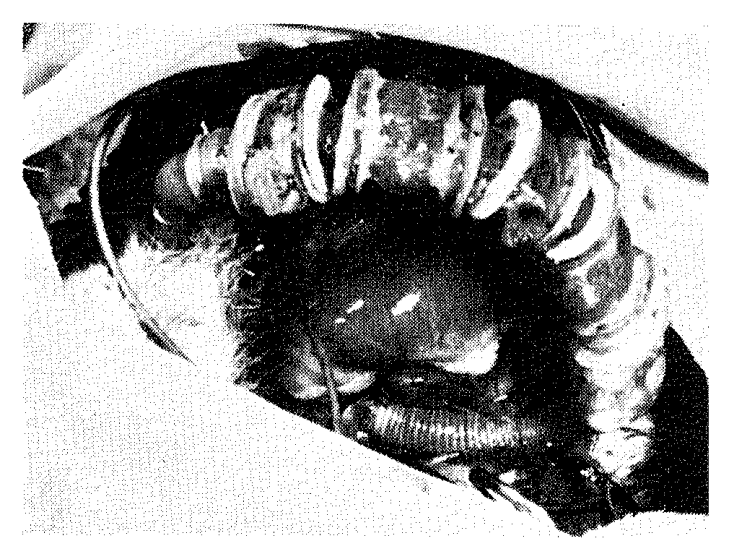

写真 4 犬の胸腔へ移植したもの, 右が 大勤脤カニューラ

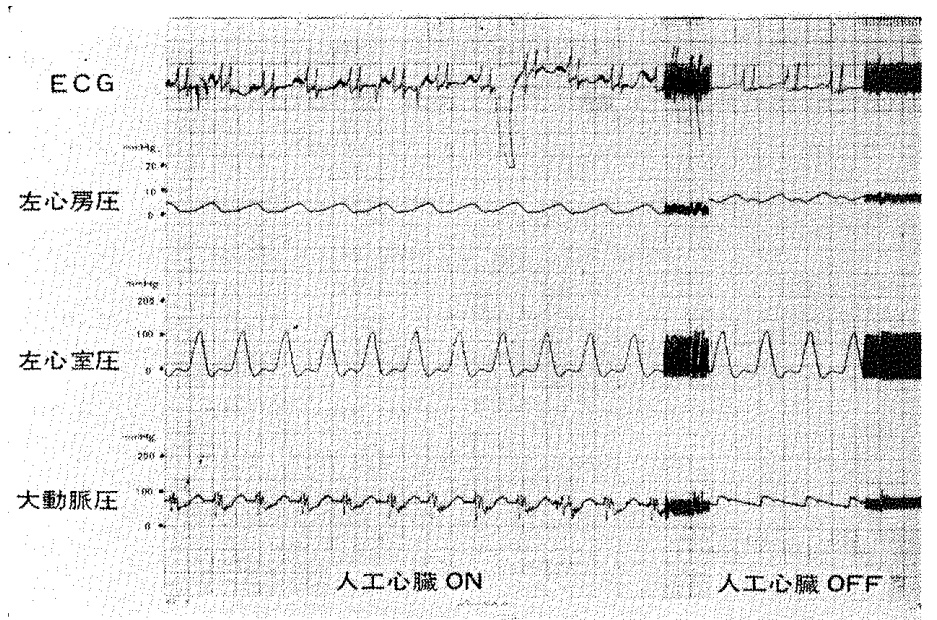

図14人エ心䑏の駆動による血圧波型の変化

みられない。

これをはばむ第 1 の問題はやはり血栓形成の 危険性である. 現在臨床に使用される人工弁で さえもこの問題に関しては完全でないのをみて も難問題であることがわかる．材料の項でのべ たようにこの目的にかなった新しい高分子材料 が開発されることが重要であるけれども, 新材
料の出現がすべてを解決するとは言い難い，心 内膜の病変が，それほど著るしくない心房細動 を伴った僧帽弁狭窄症に時に左房血栓がみられ ることからも類推できるように，人工心臓内部 での血流動態がこの問題の解決のために重要で ある. 駆動に際して人工心臓内に血液の貯溜や 停滞を起こさないよう, デザインされることが 重要である. 人工心臟の内膜にフィブリンを定 着させ, 偽内膜を形成させる方法は，これらの 高分子材料に比べてすぐれた方法である. しか しこの偽内膜の運動を考慮すると chamber の 形態には制限があり，理想的な形態にデザイン することが困難ではないかと思われる.この材 料を使用したもっとも理想的な形態が別途に追 求される必要があろう.

次に重要な問題は，これらの高分子材料の疲 労による人工心臓の破壊である. 毎分70回の人 工心臟の駆動は，1日に約10万回であり，同じ 型式のもので工業界において寿命が問題となる 場合に比べて異常に多い. 現在 total heart と して開発されている人工心臓の寿命は約 1 カ月 で, 動物に移植実験を行なって, 幸い血栓形成 そのほかの難問を免れて生存しえたもの の死因はすべて人工心臓の破裂であると いうことである ${ }^{30)}$. この問題を解決する ためにもより強い材料の開発がまたれ る. 同時に同じ材料を使用しても運動の 方法によって寿命は変化する. 1 つの材 料に適合した運動を行ならよう人工心臓 のデザインがこの面からさらに検討され る必要がある.

第 3 の問題は, 人工心臟の駆動方法 と,その効果についてである. assist heart の場合は比較的長時間にわたってバイパ ス効果が解明されそのための駆動方法も ほぼ見当づけられたが， total heart の場 合は両心の同期駆動法とそれによる末梢循環維 持に問題があるようで今後検討がすすめられよ 亏.

われわれの人工心臓は，これらの問題の $1 つ$ の解決法として考案され, 前節でのべたように 一応初期の目的は達成しえた.けれども人工心 臓自身を簡略単純化したことが，その駆動機構 
を非常に複雑なものとする結果になった，長時 間の駆動のためにはこの機構にいくつかの久点 があり現在改良中である。しかし，血栓形成之 のほかの医学の面から解決しえない問題が，現 代のエレクトロニクスの技術を使用すれば解決 しうるであるう機械的メカ二ズムの問題に置き 換えられたとすれば大きな進歩であろうと考え る.

心臟移植術が拒絶反応の問題在解決しえない 限り移植された donorの寿命に限界があるけ れども, 人工心臓の現時点におけるそ机に比心゙ 机ばはるかに長いことは否定できない。ここに 人工的な高分子材料と生体固有の材料の差がみ られる，今後，材料の検討によって人工心蔵の 寿命を飛躍的に延長させ永久臓器としてのレぶ ルまで向上させることが理想である。

Cooley は人工心臟移植後に donor 心を求め て，早期に再び心臓移植を行なった ${ }^{13)}$. 人工心 蔵のこの使用方法は, 永久臓器ではなく明らか に一定の限定された治療期間をもった治療用機 器である。

一定の期間確実に生体心機能を代行できる assist heart によってもこの目的を達成するこ とはできよう。さらに人工心臟の移植と同時に 一次的に温存された生体心に従来から研究され ている各種の心筇および冠動脈血行再建術を行 なえば，現時点で考えられている心臟移植の適 応症例を減少させる可能性が考えられる。こう いった assist heart の開発が臨床の面からは, もっとも要望されるものであろう.

（福慶逸郎助教授，榊原欣作講師のご校閲 感謝します。われわれの人工心蔵の製作に全面 的に協力いただいた泉工医科工業社長青木利三 郎氏に深じんの謝意を表しま寸。）

\section{文献}

1) Galletti, P. M. and G. A. Brecher: Heartlung bypass. p. 1, Grune and Strattor, New York, 1962.

2) Gibbon, J. H. Jr.: Application of mechanical heart and lung aparatus to cardiac surgery. Minnesota Med. 37 : 171-177, 1754.

3) Kirklin, J. W. et al: Intracardiac surgery with the aid of a mechanical pump-oxygenator system. Report of eight cases. Proc. Mayo Clin. 30 : 201-206, 1955.

4) Lillehei, C. W. et al: Direct vision intracardiac surgical correction of tetralogy of Fallot, pentalogy of Fallot and pulmonary atresia defects. Report of first ten cases. Ann. Surg, 142: 418-445, 1955.

5）曲直部寿夫ほか：人工心肺による直視下心 臓内手術臨床外科, 11：443，1956

6) Sakakibara, S: Intracardiac surgery under direct vision. Bull. Heart Inst. Japan 1 : 1-8, 1957. (cited)

7) Akutsu, T., and W. J. Kolff: Permanent substitutes for valves and hearts. Tr. Amer. Soc. Art. Int. Organs, 4:230, 1958.

8) Liotta, D. S. et al. : Prolonged partial left ventricular bypass by means of an intrathoracic pump implanted in the left chest. Tr. Amer. Soc. Art. Int. Organs, 9: 90-99, 1962.

9) Harken, D. E. : Assisted circulation. Presented before the 3 rd world congress of Cardiology, Brussels 1958. (cited)

10) Goldman, A. et al. : veno-arterial pulsatile partia! bypass for circulatory assist. Diseases of the Chest $50: 1966$.

11) Moulopoulos, S. D. et al. : Diastolic baloon pumping in the aorta mechanical assistance to the failing circulation. Am. Heart. J. $63: 5,1962$.

12) Starr, A. et al. : Mitral replacement: The shielded ball valve prosthesis, J. Thoracic. Cardiovas. Surg. $42: 673,1961$.

13) Cooley, D. et al.: Staged replacement of the human heart. Tr. of Amer. Soc. Art. Int. Organs. 15 : 252-263, 1969.

14) Bernhard, W. F. et al. : Chronic left ventricular bypass with an implantable ventricular-aortic assist pump. Circulation 39 : $98,1969$.

15) Akutsu, T. et al.: Complete ventricular atrialization by an implantable heart support device. J. Thoracic Cardiovas. Surg. $56: 421-427,1968$.

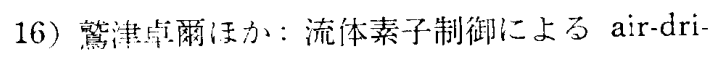


ven 血液ポンプ，日臟会誌 $6: 116,1968$.

17) Nose, U. et al. : Clot formation inside the artificial heart device. J. Thoracic Cardiovas. Surg. 54: 697-706, 1967.

18) The artificial heart program of national Heart and Lung Institute, Annual Report, July through June 30,1970 . AH 27.

19) The artificial heart program of National Heart and Lung Institute. Annual Report, July 1969 through June 30, 1970, AH-28.

20) The artificial heart program of National Heart and Lung Institute, Annual Report, July 1, 1969 through June 30, 1970. AH-26.

21) The artificial heart program of National Heart and Lung Institute, Annual Report, July 1, 1969 through June 30, 1970. AH-34.

22) Bernhard., W. F., et al, : An improved blood interface for left ventricular bypass. Ann. of Surg., 168: 750-764, 1968.

23) Liotta, D., et al. : A pseudo endocardium for imlpantable blood pumps. Tr. Amer. Soc. Ar. Int. Organs. 12: 129-134, 1966.
24) Washizu, T.: A new left heart assist device without the conventional type valve. TECHNOCRAT. $3:$ 46-47, 1969.

25) The artificial heart program of the National Heart and Lung Institute. Annual Re. port, July 1, 1969 through June 30, 1970. AH. 77-AH. 94.

26) Akutsu, T., et al.: Roller typy of artificial heart within the chest. Amer. Heart., J. 59 : 731, 1960.

27) Akutsu, T., et al.: An electromotor driven pendulum-type artificial heart inside the chest. Tr. Amer. Soc. Ar. Int. Organs, $7: 374,1961$.

28）熟津卓爾ほか：流体素子による air-driven 血液ポンプの研究, 第 8 [回日本 $M E$ 学会大 会予稿集, 172-173, 1969.

29）熟津卓爾：われわれの開発した人工心臓、日 臟会誌 $7: 73-78,1970$.

30）阿久津哲造：座談会 “人工心藏”岡山会館 阔山市 9 月 4 日 1970 .

\section{新 発売!! \\ 丸型カストの決 定 版}

最商級 18-8ステンレス・スチール製

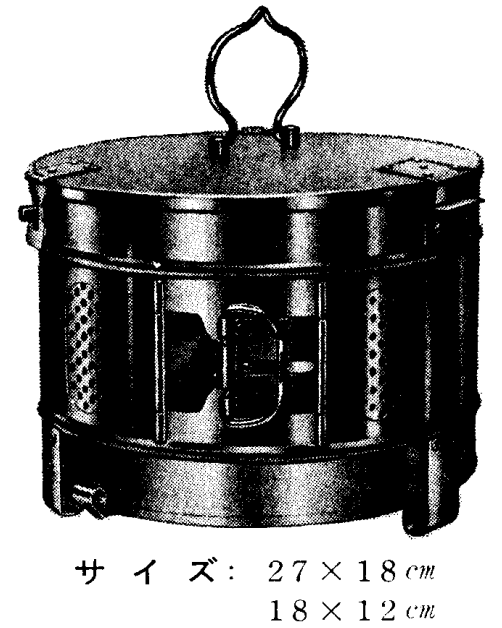

特 長

カストの最も重要な点は胴の蒸気孔の開閉がスムー ズで，しかも確実に閉されることです。

従来のカストの開閉バンドはネジで締めつけたまま 移動寸るために胴上バンドとの隙間が大きく，したが って蒸気孔を確実に閉すことは困難です。

このカストは大変ご好評をいただいております防衛 预型カストの開閉機構を採用したもので, 開閉バンド をハンドルの操作によってゆるめて移動し，ハンドル を反対側にた抽して開閉バンドを固定しますので，蒸 気孔の開闒がスムーズであり，かつ確奏に閉されま す。

\section{SAKATA 禁嶻坂田機械製作 所}

東京都台東区根岸 $5-2-9$ 電話 東京 (03) 872-1854 